\title{
Biologia Plantarum founded 50 years ago
}

The first number of Biologia Plantarum has been issued in 1959. It was an international journal for experimental botany and the first valid medium for the Czech plant biologists.

It was also a serious break of the steel wires which at that time were sealing our country's borders. Favourable conditions were given by Chruschov's then more benevolent approach to politics, and also by the newly established Academy of Sciences with larger range of Institutes, which felt the need to inform the world about their first important scientific results.

On the subject of plant physiology new interest was directed to photosynthesis, water relations, and plant ontogenesis. New experimental branches appeared within phytopathology and plant genetics. However, there was a surplus of enthusiasm, but experience in method was sorely lacking and there wasn't enough background and local facilities. In the newly established experimental centres people knew that the true sources of knowledge were in the more developed western states, nevertheless the political indicators were steadily showing in the other direction. In such conditions the possibility of establishing international contacts for further development of the local science were of crucial importance. This roll fulfilled in no small measure Biologia Plantarum.

At it's birth stood a famous scientist Bohumil Nèmec who became the editor in chief. Then Bohdan Slavik, as executive editor, and the political and social path for the new journal opened Ivan Málek, Director of Biological Institutes of the Czechoslovak Academy of Sciences. The number of foreign authors grew steadily and the editorial board was soon joined by such personalities as F.W.Went, P. Meheshwari, H. Stubbe, and others. Many of them helped the local contributors to overcome pitfalls of scientific English and taught them the art of scientific writing.

Now, leafing nostalgically through yellow pages of the first annual volume, we are remembering friends and colleagues. Bohdan Slavik is the last survivor of those glorious days. The first four numbers are silently speaking of the times and their own establishment. More than $90 \%$ of articles were written by local contributors. More than half of them dealt with plant physiology, one quarter belonged to phytopathology and the rest to genetics, ecophysiology, cytology and methods. About $70 \%$ of publications were in English, the rest in German and Russian.

Today, after fifty years the journal looks rather different. It acquired all the aspects of a modern international communication scientific medium. What has not changed is it's field of interest, howerer, there is overhelming majority of exterior contributors, and impact factor during the last four years grew from 0.74 to 1.43 .

Looking back we are grateful to all who stood at the birth of Biologia Plantarum. We also appreciate work of the contemporary editors, local and foreign authors and editorial staff. On its $50^{\text {th }}$ Birthday we wish the journal good health and the ever growing impact factor.

J. Krekule (Prague) 